\title{
SKRINING FITOKIMIA, KANDUNGAN FLAVONOID TOTAL, DAN AKTIVITAS ANTIOKSIDAN EKSTRAK ETANOL TUMBUHAN Selaginella doederleinii
}

\author{
Farida Dwi Oktavia, Suyatno Sutoyo* \\ Jurusan Kimia, Fakultas Matematika dan Ilmu Pengetahuan Alam, Universitas Negeri Surabaya \\ *email : suyatno@unesa.ac.id
}

Received 24 Oktober 2021

Accepted 3 Desember 2021

\begin{abstract}
Abstrak
Selaginella doederleinii merupakan tumbuhan paku yang berasal dari China, namun telah dibudidayakan di Indonesia. Tumbuhan tersebut dimanfaatkan oleh masyarakat untuk melancarkan aliran darah, menghilangkan bengkak, antitoksik, antikanker, dan menghentikan pendarahan (hemostatis). Penelitian ini bertujuan untuk menentukan kandungan fitokimia, kandungan flavonoid total, aktivitas antioksidan dari ekstrak etanol tumbuhan $S$. doederleinii. Ekstraksi dilakukan menggunakan metode maserasi dan dihasilkan ekstrak etanol berupa padatan berwarna hijau gelap. Ekstrak padat dianalisis metabolit sekundernya menggunakan skrining fitokimia. Kadar flavonoid total ditentukan menggunakan spektroskopi dengan pereaksi aluminium klorida. Aktivitas antioksidan ditentukan menggunakan metode DPPH. Hasil skrining fitokimia ekstrak etanol $S$. doederleinii terdapat kandungan fenolik, alkaloid, saponin, steroid, flavonoid, dan tanin. Kandungan flavonoid total ekstrak etanol tumbuhan S. doederleinii sebesar 17,615 mg QE/g ekstrak. Sementara itu nilai IC 50 pada uji aktivitas antioksidan sebesar 128,696 ppm, sehingga ekstrak etanol $S$. doerdeleinii mempunyai aktivitas antioksidan dalam kategori sedang.
\end{abstract}

Kata kunci: Selaginella doederleinii, kandungan flavonoid total, aktivitas antioksidan

\begin{abstract}
Selaginella doederleinii is one of the ferns originating from China, but has been cultivated in Indonesia. These plants used by the community to improve blood flow, eliminate swelling, antitoxic, anticancer, and stop bleeding (hemostasis). This research was conducted to determine the phytochemical content, total flavonoids content, and antioxidant activity of the ethanol extract of $S$. doederleinii. Extraction was carried out by maceration method and the resulting extract was a dark green solid. The ethanol extract was analyzed for its secondary metabolite content by phytochemical screening. Determination of the total flavonoid content was determined using spectroscopic with an aluminium chloride reagent. The antioxidant activity was determined using the DPPH method. The results of phytochemical screening the ethanolic extract of $S$. doederleinii contained phenolics, alkaloids, saponins, steroids, flavonoids, and tannins. The flavonoid content in the ethanol extract of S. doerdeleinii was 17,615 mg QE/gram extract. Based on the antioxidant activity test, it was obtained the $\mathrm{IC}_{50}$ value of $128.696 \mathrm{ppm}$, so the ethanol extract of $S$. doederleinii had moderate antioxidant activity.
\end{abstract}

Keywords: Selaginella doederleinii, total flavonoids content, antioxidant activity 


\section{Pendahuluan}

Tumbuhan paku Selaginella doederleinii merupakan tumbuhan paku yang berasal dari China dan sudah banyak dikembangkan di Indonesia. Masyarakat mengenal tumbuhan paku tersebut dengan nama rumput Solo dan cemara kipas gunung (Dalimartha, 1999). S. doederleinii secara spontan tumbuh di pesisir sungai, permukaan batuan dan bilik tebing yang basah (Hutapea, 1999). Tanaman ini memiliki khasiat meminimalisir panas dan kelembapan, memperlancar peredaran darah, bersifat antitoksik, antineoplasma, hemostasis, serta meredakan bengkak. Tanaman ini memiliki keefektifan untuk mengobati batuk, diare, kanker, kelainan saluran pernapasan, pembengkakan paruparu, hepatitis, keputihan, dan patah tulang. (Dalimartha, 1999).

Tumbuhan paku S. doerdeleinii dilaporkan terdapat kandungan alkaloid, saponin, dan fitosterol (Dalimartha, 1999). Keberadaan senyawa flavonoid dan lignan mendukung bahwa tumbuhan paku $S$. doederleinii memiliki potensi sebagai aktioksidan (Lin, et al., 1994). Namun demikian, dari sejumlah penelitian terkait, belum banyak ditemukan kandungan senyawa metabolit sekunder $S$. doerdeleinii yang lebih kompleks dan bervariasi, maka dari itu untuk melengkapi senyawa metabolit sekunder perlu dilakukan uji skrining fitokimia. Selain itu, setiap tanaman mengandung senyawa metabolit sekunder yang berbeda-beda bergantung pada dimana letak tumbuhnya (Chikmawati, et al., 2013). Pada penelitian ini menggunakan tumbuhan $S$. doederleinii yang diambil pada tempat yang berbeda dari penelitian sebelumnya.

Antioksidan dibutuhkan untuk mencegah timbulnya stres oksidatif dan kerusakan sel, dimana berperan penting dalam perkembangan berbagai macam penyakit degeneratif seperti kanker, penyakit arteri koroner, dan stroke. Berbagai bukti ilmiah telah ditunjukkan bahwa risiko penyakit yang disebabkan radikal bebas kronis mampu dikurangi dengan memakai berbagai macam senyawa antioksidan meliputi antosianin, karotenoid, stilben, dan flavonoid. (Paknahad, et al., 2020). Dalam penelitian ini akan dilakukan pengujian skrining fitokimia, kandungan total flavonoid, serta aktivitas antioksidan terhadap ekstrak etanol tumbuhan paku S. doederleinii.

\section{Metode Penelitian}

\section{Alat dan bahan}

Peralatan yang digunakan yaitu vacuum pump (Gast DOA-P-504-BN), seperangkat alat rotavapor (Buchi B-491), neraca analitik (Advanturer Ohaous), magnetic stirrer, freeze dryer (Christ Alpha 1-2 Ldplus), spektrofotometer UV-Vis (Shimadzu UV-1800), oven (Heraeus ST5042), corong Buchner, spatula, cawan petri, plat tetes, mikropipet (Dragon Lab), stopwatch, labu ukur (Pyrex), gelas kimia(Iwaki), tabung reaksi (Pyrex), gelas ukur (Herma), botol vial.

Bahan-bahan yang digunakan meliputi serbuk kering bagian aerial tumbuhan $S$. doederleinii, etanol p.a., pita $\mathrm{Mg}$, etanol 96\% teknis, larutan $\mathrm{FeCl}_{3}$ (1\% dan 5\%), kertas saring whatman No.1, aquades, $\mathrm{HCl}$ (1M dan $2 \mathrm{M}$ ), metanol p.a., $\mathrm{H}_{2} \mathrm{SO}_{4}$ pekat, reagen Mayer, reagen Dragendorff, reagen Wagner, ammonia, $\mathrm{AlCl}_{3} 10 \%$, asam asetat anhidrida, $\mathrm{HCl}$ pekat, kuersetin (Sigma), kalium asetat 1M, DPPH (Sigma).

\section{Pengambilan dan Persiapan Sampel}

Dalam penelitian ini sampel penelitian yaitu bagian aerial tumbuhan paku $S$. doederleinii didapatkan dari UPT Balai Materia Medica, Kota Batu, Jawa Timur. Pada penelitian ini diawali dengan mengidentifikasi sampel di LIPI Kebun Raya Purwodadi, Jawa Timur. Tumbuhan $S$. doederleinii dicuci dengan air hingga bersih dari kotoran-kotoran yang menempel, selanjutnya didiamkan dalam suhu ruang. Lalu sampel digiling hingga menjadi serbuk.

Sejumlah 1000 gram serbuk kering tumbuhan $S$. doederleinii dimaserasi 
dengan 1,5 L etanol $96 \%$ teknis dalam waktu 24 jam dengan suhu ruang. Selanjutnya dilakukan penyaringan menggunakan corong Buchner. Ekstrak cair yang didapatkan kemudian dilakukan evaporasi dengan rotavapor, dilanjutkan pengeringan dengan freeze dryer sehingga diperoleh ekstrak etanol padat tumbuhan paku S. doederleinii berwarna hijau gelap.

\section{Uji Kualitatif Hasil Ekstraksi}

\section{1) Alkaloid}

Ditimbang $4 \mathrm{mg}$ sampel padat dilarutkan menggunakan $3 \mathrm{~mL}$ metanol dan $5 \mathrm{~mL}$ amonia pada $\mathrm{pH}$ sekitar 8-9, kemudian hasil pencampuran tersebut disaring. Selanjutnya $2 \mathrm{~mL}$ larutan $\mathrm{HCl}$ 2M ditambahkan pada filtrat dan dikocok. Hasil yang didapatkan dimasukkan dalam 4 tabung reaksi masing-masing 5 tetes. Tabung 1 berisi larutan blanko, sedangkan tabung 2, 3, dan 4 akan dicampur dengan 1 tetes pereaksi Mayer, Wagner, Dragendorff pada setiap tabung. Hasil positif pada pengujian ini ditunjukkan dengan masing-masing larutan terdapat endapan putih, coklat atau jingga (Suyani, 1991).

2) Flavonoid

Sejumlah $1 \mathrm{mg}$ ekstrak etanol padat ditempatkan pada plat tetes, lalu dimasukkan 10 tetes metanol, diaduk menggunakan spatula sampai larut. Selanjutnya ditambahkan 6 potongan pita $\mathrm{Mg}$ dan $\mathrm{HCl}$ pekat 4 tetes ke dalam campuran. Timbulnya warna kuning, biru, jingga maupun merah menunjukkan hasil positif (Octaviani, et al., 2019).

\section{3) Fenolik}

Sejumlah $1 \mathrm{mg}$ sampel padat diletakkan dalam plat tetes, kemudian menambahkan 10 tetes metanol, lalu diaduk menggunakan spatula sampai larut. Selanjutnya ditambahkan 6 tetes larutan $\mathrm{FeCl}_{3}$ 5\%. Warna biru, hijau, ungu, atau kemerahan kemerahan menandakan hasil positif pada pengujian (Suyani, 1991).
4) Saponin

Sebanyak $1 \mathrm{mg}$ ekstrak etanol padat diletakkan pada tabung reaksi, lalu menambahkan $5 \mathrm{~mL}$ aquades dan digoyang selama 1 menit. Jika terbentuk buih, ditambahkan 4 tetes larutan $\mathrm{HCl} 1 \mathrm{M}$. Jika tidak ada buih, dilanjutkan pemanasan \pm 3 menit. Kemudian dibiarkan dingin lalu dikocok kuat-kuat. Terbentuknya buih stabil dalam waktu \pm 10 menit menandakan terdapat senyawa saponin dalam sampel. (Triwahyuono \& Hidajati, 2020).

5) Tanin

Sebanyak $1 \mathrm{mg}$ sampel padat dilarutkan dalam etanol, kemudian ekstrak dididihkan dengan air dalam penangas air, selanjutnya dilakukan penyaringan. Menambahkan 3 tetes $\mathrm{FeCl}_{3} 1 \%$ ke dalam filtrat yang diperoleh. Hasil positif dapat dilihat berdasarkan terbentuknya warna pada sampel yaitu biru tua dan hitam kehijauan. $\mathrm{FeCl}_{3}$ digunakan untuk mengidentifikasi gugus fenol, jika dalam senyawa terdapat gugus fenol, maka terdapat juga tanin, karena tanin adalah senyawa polifenol (Jati, et al., 2019).

6) Steroid dan Triterpenoid (Uji Liebermann-Burchard)

Sejumlah $1 \mathrm{mg}$ sampel padat etanol diletakkan pada plat tetes, ditambahkan 6 tetes asam asetat anhidrat, kemudian diaduk menggunakan spatula sampai larut. Selanjutnya ditambahkan satu tetes $\mathrm{H}_{2} \mathrm{SO}_{4}$ pekat. Jika terbentuk warna ungu hingga jingga dalam larutan menunjukkan terdapat senyawa triterpenoid, sedangkan jika berwarna biru atau hijau menunjukkan terdapat senyawa steroid (Suyani, 1991).

\section{Uji Flavonoid Total}

Ditimbang $25 \mathrm{mg}$ serbuk kuersetin dilarutkan menggunakan etanol p.a hingga menghasilkan larutan standar kuersetin 1000 ppm. Larutan standar kuersetin dibuat bervariasi konsentrasi sebesar 20 , 30, 40, 50, dan 60 ppm. Larutan standar kuersetin diambil sebanyak 0,5 mL kemudian ditambahkan $1,5 \mathrm{~mL}$ etanol p.a., $0,1 \mathrm{~mL} \mathrm{AlCl}{ }_{3} 10 \%, 0,1 \mathrm{~mL} \mathrm{CH}_{3} \mathrm{COOK} 1 \mathrm{M}$ lalu $2,8 \mathrm{~mL}$ aquades. Dilakukan inkubasi 
dalam waktu 30 menit. Selanjutnya ditentukan panjang gelombang maksimum, mengambil larutan $40 \mathrm{ppm}$, diukur panjang gelombang dengan rentang 400-800 nm (Haeria \& Andi, 2016). Larutan standar yang digunakan merupakan larutan dengan konsentrasi yang berada di tengah-tengah larutan standar kuersetin (Trinovita, et al., 2019). Panjang gelombang ditentukan bertujuan untuk mengetahui nilai absorbansi maksimal pada sampel (Gandjar \& Rohman, 2007).

Menimbang $50 \mathrm{mg}$ sampel ekstrak etanol tumbuhan paku $S$. doederleinii kemudian dicukupkan dengan etanol p.a. hingga mencapai konsentrasi 5000 ppm. Selanjutnya menambahkan $0,5 \mathrm{~mL}$ sampel uji dengan 1,5 mL etanol p.a., 0,1 mL $\mathrm{AlCl}_{3} 10 \%, 0,1 \mathrm{~mL} \mathrm{CH} \mathrm{CH}_{3} \mathrm{COOK} 1 \mathrm{M}, 2,8$ $\mathrm{mL}$ aquades. Kemudian dilakukan inkubasi selama 30 menit. Untuk mengukur absorbansi digunakan spektrofotometer UV-Vis, panjang gelombang maksimum yang digunakan yaitu $435 \mathrm{~nm}$, diperoleh dari percobaan sebelumnya. Kandungan flavonoid total pada sampel tumbuhan paku $S$. doederleinii dapat dicari dengan persamaan pada kurva kalibrasi larutan kuersetin yang diperoleh. Pengukuran dilakukan secara triplo (Haeria \& Andi, 2016).

\section{Uji Aktivitas Antioksidan}

Ditimbang $5 \mathrm{mg}$ ekstrak etanol tumbuhan paku S. deoderleinii, selanjutnya dilarutkan dengan etanol p.a. hingga diperoleh konsentrasi larutan induk 500 ppm (Taba, et al., 2019). Untuk menghasilkan DPPH konsentrasi $4 \mathrm{mM}$, ditimbang DPPH sejumlah 0,0157 gram, kemudian dicukupkan menggunakan etanol p.a. dalam labu ukur $100 \mathrm{~mL}$. Larutan yang dihasilkan selanjutnya disimpan pada botol gelap serta dalam ruangan gelap (Taba, et al., 2019).

Larutan ekstrak dibuat dengan 5 variasi konsentrasi yaitu 10, 20, 40, 80, 160 ppm.
Diambil sebanyak 0,$1 ; 0,2 ; 0,4 ; 0,8 ; 1,6$ $\mathrm{mL}$ dari larutan induk $500 \mathrm{ppm}$. Kemudian ditambahkan $1 \mathrm{~mL}$ larutan DPPH pada labu ukur $5 \mathrm{~mL}$ dicukupkan menggunakan etanol p.a., kemudian campuran dikocok sampai homogen. Selanjutnya campuran diinkubasi 30 menit pada ruangan yang gelap serta pada suhu ruang. Absorbansi setiap sampel ditentukan dengan panjang gelombang $514 \mathrm{~nm}$ (didapatkan dari larutan induk $500 \mathrm{ppm}$ ) (Farah, et al., 2019). Persentase inhibisi radikal bebas DPPH dapat ditentukan dalam persamaan 1.

$\%$ Inhibisi $=\frac{\text { A blanko-A ekstrak }}{\text { A blanko }} \times 100 \% \ldots \ldots$

Setelah didapatkan nilai \%inhibisi radikal $\mathrm{DPPH}$, akan diketahui nilai $\mathrm{IC}_{50}$ melalui analisis grafik hubungan antara persentase inhibisi yang didapatkan pada tiap konsentrasi larutan sampel. Nilai IC $_{50}$ menunjukkan konsentrasi larutan sampel dapat meredam 50\% absorbansi larutan DPPH (Taba, et al., 2019).

\section{Hasil dan Pembahasan}

Pada penelitian ini digunakan metode maserasi karena mudah untuk dilakukan dan menggunakan alat-alat yang cukup sederhana. Prosesnya sangat efektif dalam mengekstraksi senyawa dari bahan alam, hal ini membuat tanaman sampel mengalami penguraian pada dinding serta membran sel yang mengakibatkan perbedaan tekanan diantara dalam sel dan luar sel, oleh karena itu metabolit sekunder akan larut dengan pelarut organic. Tanpa pemanasan juga menjadi salah satu kelebihan metode maserasi agar senyawa metabolit yang akan dianalisis tidak rusak (Pasaribu, 2009). Didapatkan hasil maserasi berupa ekstrak padat berwarna hijau gelap dengan berat 99,028 gram. Hasil dari pengujian fitokimia ditunjukkan dalam Tabel 1. 
Tabel 1. Hasil Uji Fitokimia Ekstrak Etanol S. doederleinii

\begin{tabular}{|c|c|c|c|}
\hline Uji Fitokimia & Hasil & Pengamatan & Gambar \\
\hline Fenolik & + & Terbentuk warna ungu & \\
\hline Flavonoid & + & Terbentuk warna jingga & \\
\hline Alkaloid & & & \\
\hline - Mayer & + & Endapan putih & \\
\hline - Wagner & + & Endapan coklat & \\
\hline - Dragendorff & + & Endapan jingga & \\
\hline Saponin & + & Terbentuk buih & \\
\hline
\end{tabular}


Steroid $\quad+\quad$ Terbentuk warna hijau kebiruan

Tanin $\quad+\quad$ Terbentuk warna hijau kehitaman



Dari data yang dihasilkan dalam pengujian fitokimia tersebut mengindikasikan bahwa ada senyawa metabolit sekunder yaitu flavonoid, alkaloid, fenolik, steroid, saponin, dan tanin pada sampel etanol tumbuhan paku Selaginella doederleinii.

Hasil penelitian sebelumnya tentang tumbuhan paku genus Selaginella yang banyak diteliti yaitu $S$. willdenowii. Tumbuhan $S$. willdenowii memiliki kandungan fenolik, flavonoid, alkaloid, saponin, dan tanin (Rindita, et al., 2020).

\section{Hasil Uji Alkaloid}

Pada pengujian ini menunjukkan bahwa ekstrak etanol tumbuhan $S$. doederleinii mengandung senyawa alkaloid dibuktikan terdapat endapan berwarna putih dalam Mayer, endapan coklat dalam Wagner, dan endapan jingga dalam Dragendorff. Endapan dihasilkan karena terjadi pembentukan kompleks kalium-alkaloid. Alkaloid memiliki pasangan elektron bebas pada atom nitrogen yang akan berikatan dengan ion $\mathrm{K}^{+}$dalam pereaksi alkaloid (McMurry \& Fay, 2004).

Persamaan reaksi percobaan ini terlihat pada Gambar 1 sampai 3.

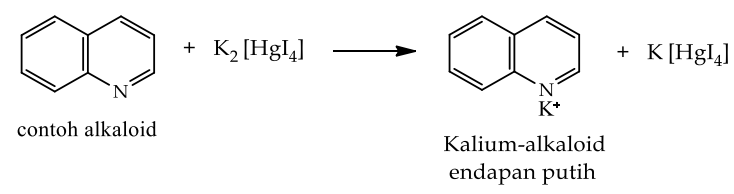

Gambar 1. Persamaan reaksi Mayer

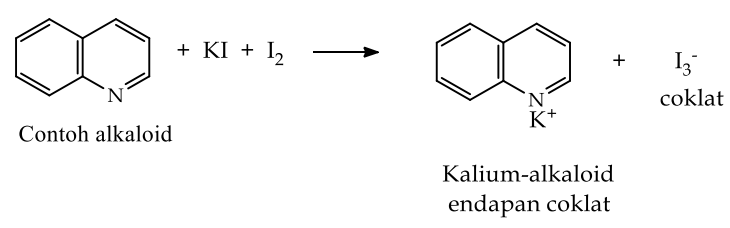

Gambar 2. Persamaan reaksi Wagner

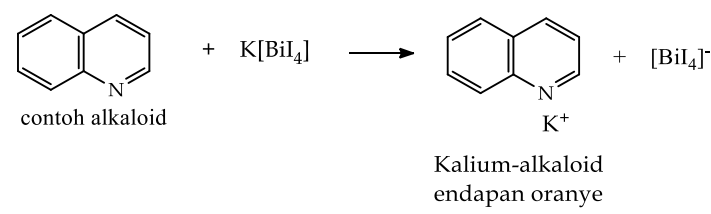

Gambar 3. Persamaan reaksi Dragendorff (Setiabudi \& Tukiran, 2017)

\section{Hasil Uji Flavonoid}

Pengujian kadar flavonoid total dengan menggunakan pereaksi Shinoda. Dihasilkan perubahan warna larutan menjadi berwarna jingga dikarenakan senyawa kompleks dari ion magnesium dengan ion fenoksi pada senyawa flavonoid. Reduksi senyawa flavonoid yang terkandung dalam ekstrak dengan $\mathrm{Mg}^{2+}$ dan $\mathrm{HCl}$ pekat akan membentuk kompleks $\left[\mathrm{Mg}(\mathrm{OAr})_{6}\right]^{4-}$ yang berwarna jingga (Marliana, 2005). Persamaan reaksi yang terlibat dalam pengujian ini terlihat pada Gambar 4. 


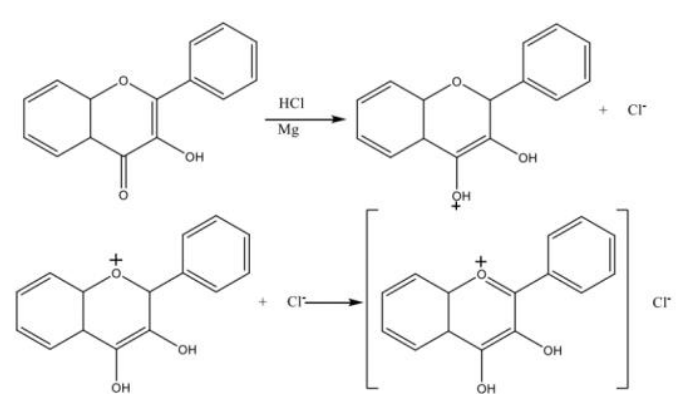

Gambar 4. Reaksi flavonoid dengan Magnesium (Setiabudi \& Tukiran, 2017)

\section{Hasil Uji Fenolik}

Pada percobaan ini didapatkan ekstrak etanol tumbuhan $S$. Doederleinii berubah warna menjadi ungu, menunjukkan bahwa dalam sampel terkandung senyawa fenol. Warna ungu timbul akibat terbentuknya senyawa kompleks antara ion ferri dan ion fenoksida yaitu $\left[\mathrm{Fe}(\mathrm{OAr})_{6}\right]^{3 .}$ Reaksi terlihat pada Gambar 5.

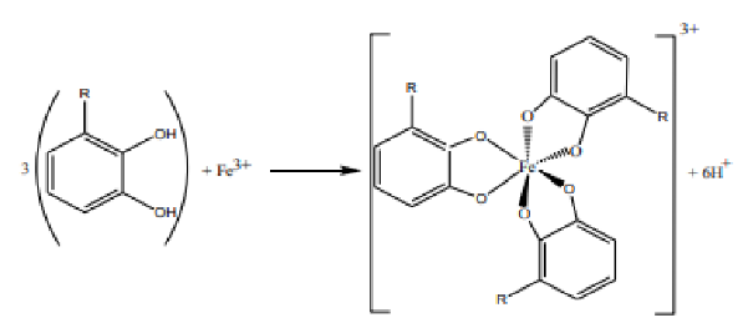

Gambar 5. Reaksi dengan ferri klorida (Jati, et al., 2019)

\section{Hasil Uji Saponin}

Pada pengujian senyawa saponin menggunakan metode "Forth". Hasil yang didapatkan dalam pengujian ini timbul buih yang stabil dengan tinggi $2 \mathrm{~cm}$ dalam waktu \pm 10 menit. Timbul buih yang stabil disebabkan karena glikosida memiliki kemampuan memperoleh buih pada air lalu mengalami hidrolisis menjadi glukosa serta senyawa lainnya. Persamaan reaksi pembentukkan buih pada saponin disajikan dalam Gambar 6.



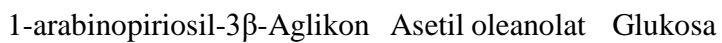
Gambar 6. Persamaan reaksi pengujian senyawa saponin (Setiabudi \& Tukiran, 2017)

\section{Hasil Uji Tanin}

Pengujian senyawa tanin dalam ekstrak etanol S. doederleinii setelah ditetesi larutan $\mathrm{FeCl}_{3}$ terbentuk larutan berwarna hijau kehitaman yang menandakan terbentuk senyawa kompleks (tanin dan ion $\mathrm{Fe}^{3+}$ ). Reaksi terlihat pada Gambar 7 .<smiles>CC1Cc2ccc(O)cc2CC1c1ccc(O)c(O)c1</smiles>

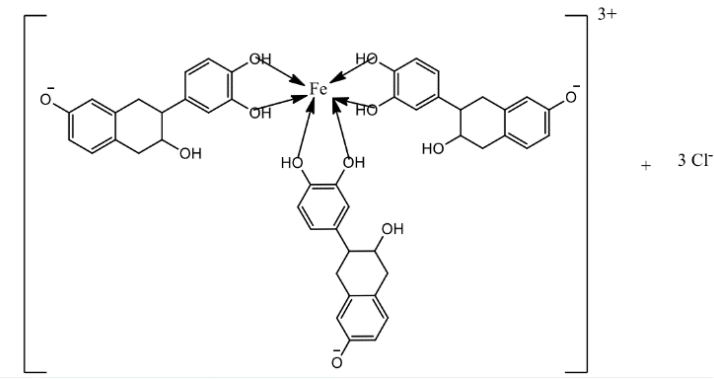

Gambar 7. Reaksi Tanin dengan Polifenol dan Ferri Klorida (Sulasmi, et al., 2019)

\section{Hasil Uji Steroid}

Pada pengujian steroid ekstrak etanol $S$. doederleinii dihasilkan larutan berwarna menjadi hijau kebiruan. Penyebabnya karena golongan steroid mengalami oksidasi yang akan membentuk ikatan rangkap terkonjugasi (Sriwahyuni, 2010). Persamaan reaksi ditunjukkan pada Gambar 8. 


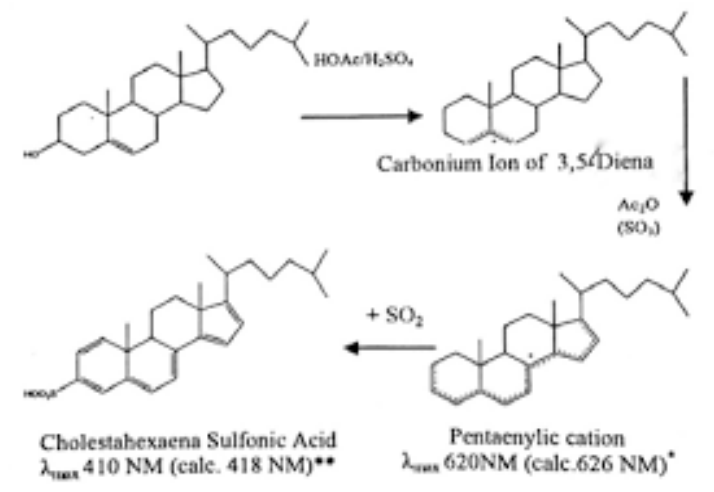

Gambar 8. Senyawa steroid dengan asam asetat anhidrida dan $\mathrm{H}_{2} \mathrm{SO}_{4}$ (Simaremare, 2014)

\section{Kandungan Flavonoid Total}

Analisis flavonoid diuji dengan metode spektrofotometri UV-visible. Kuersetin digunakan sebagai larutan standar karena termasuk kedalam jenis flavonoid sebagai standar pembanding dalam menentukan kandungan flavonoid total, serta memiliki aktivitas antioksidan yang tinggi (Lindawati \& Ma'ruf, 2020).

Pada penelitian ini dihasilkan panjang gelombang maksimum sebesar $435 \mathrm{~nm}$. Selanjutnya larutan kurva baku kuersetin dibuat untuk menghitung konsentrasi sampel melalui persamaan regresi linier yang dihasilkan (Gandjar \& Rohman,
2007). Pada percobaan ini digunakan metode kolorimetri yaitu dengan mereaksikan aluminum klorida, metode ini juga relatif sederhana untuk pengujian flavonoid golongan flavon esensial dan flavonol dapat bereaksi dengan Al (III) (Octaviani, et al., 2019).

Senyawa flavonoid tumbuhan $S$. doerdeleinii yang telah diidentifikasi menghasilkan warna jingga pada reaksi Shinoda. Warna jingga menandakan bahwa terdapat kandungan flavonoid golongan flavon, auron atau khalkon (Winarti, et al., 2007). Sedangkan pada golongan flavonoid lain terbentuk warna merah muda (flavonol), warna merah (2,3 dihidroflavonol), dan warna ungu (xanthone) (Depkes, 1989).

Dilakukan pengukuran absorbansi variasi konsentrasi pada panjang gelombang maksimum $435 \mathrm{~nm}$. Dalam pengukuran dilakukan secara triplo. Pengulangan pengukuran bertujuan untuk meningkatkan ketepatan percobaan. Hasil pengukuran pada absorbansi larutan standar kuersetin terlihat dalam Tabel 2. Berdasarkan data Tabel 2 dapat dibuat kurva baku konsentrasi larutan kuersetin. Diperoleh kurva pada Gambar 9.

Tabel 2. Hasil larutan standar kuersetin

\begin{tabular}{ccccc}
\hline $\begin{array}{c}\text { Konsentrasi larutan kuersetin } \\
\text { (ppm) }\end{array}$ & \multicolumn{4}{c}{ Absorbansi } \\
\cline { 2 - 5 } & $\mathbf{1}$ & $\mathbf{2}$ & $\mathbf{3}$ & A rata-rata \\
\hline 20 & 0,168 & 0,170 & 0,172 & 0,17 \\
40 & 0,262 & 0,264 & 0,266 & 0,264 \\
50 & 0,331 & 0,335 & 0,333 & 0,333 \\
60 & 0,417 & 0,423 & 0,420 & 0,420 \\
& 0,509 & 0,507 & 0,508 & 0,508 \\
\hline
\end{tabular}




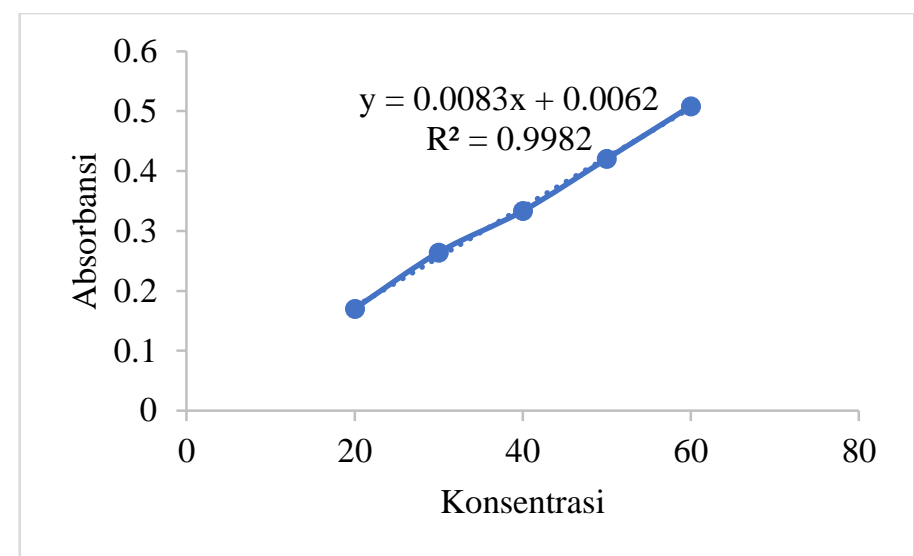

Gambar 9. Kurva baku larutan kuersetin

Pengukuran kandungan flavonoid total didasarkan hasil persamaan regresi linier pada Gambar 9 yakni y $=0,0083 x+0,0062$ dimana $\mathrm{R}^{2}$ yang didapatkan sebesar 0,9982 dan $\mathrm{r}$ sebesar 0,999. Hal tersebut menunjukkan bahwa kurva baku yang didapatkan linear dan konsentrasi larutan kuersetin dengan nilai serapan saling berhubungan (Widyasari, et al., 2019).

Selanjutnya dilakukan pengukuran kandungan flavonoid total ekstrak etanol $S$. doederleinii berdasarkan persamaan regresi linier dari kurva baku yang diperoleh (Gambar 9). Hasil pengukuran absorbansi ekstrak etanol tumbuhan paku $S$. doederleinii berturut-turut sebesar 0,7370; 0,7374; dan 0,7372. Dan didapat rata-rata absorbansi sebesar 0,7372. Berdasarkan kurva baku larutan flavonoid kuersetin dihasilkan nilai konsentrasi sebesar 88,072 $\mu \mathrm{g} / \mathrm{mL}$. Selanjutnya dengan mempertimbangkan faktor pengenceran diperoleh kandungan flavonoid total dalam ekstrak etanol $S$. doederleinii sebesar sebesar $17,615 \mathrm{mg}$ QE/g ekstrak. Kandungan flavonoid total dari ekstrak etanol $S$. doederleinii didukung oleh hasil skrining fitokimia yang menunjukkan keberadaan senyawa fenolik dan senyawa flavonoid dalam ekstrak tersebut.

\section{Aktivitas Antioksidan}

Prinsip metode DPPH adalah terjadinya transfer elektron dari senyawa antioksidan ke radikal bebas DPPH, sehingga diperoleh molekul radikal bebas yang stabil. Terjadinya reaksi tersebut ditandai dengan berubahnya warna larutan DPPH dari warna ungu hingga warna kuning muda (George, et al., 2015). Hasil aktivitas antioksidan ekstrak etanol tumbuhan paku S. doederleinii disajikan pada Tabel 3.

Tabel 3. Hasil aktivitas antioksidan tumbuhan S. doederleinii

\begin{tabular}{cccccc}
\hline $\begin{array}{c}\text { Konsentrasi } \\
\text { larutan kuersetin } \\
(\mathbf{p p m})\end{array}$ & $\mathbf{1}$ & $\mathbf{2}$ & $\mathbf{3}$ & rata-rata & \% Inhibisi \\
\cline { 2 - 5 } kontrol & 0,7316 & 0,7316 & 0,7316 & 0,7316 & 0 \\
$\mathbf{1 0}$ & 0,6841 & 0,6838 & 0,6841 & 0,6840 & 6,506 \\
$\mathbf{2 0}$ & 0,6541 & 0,6543 & 0,6545 & 0,6543 & 10,566 \\
$\mathbf{4 0}$ & 0,5745 & 0,5745 & 0,5748 & 0,5746 & 21,459 \\
$\mathbf{8 0}$ & 0,4781 & 0,4783 & 0,4782 & 0,4782 & 34,636 \\
$\mathbf{1 6 0}$ & 0,2943 & 0,2948 & 0,2944 & 0,2945 & 59,746 \\
\hline
\end{tabular}


Dalam penelitian ini kekuatan aktivitas antioksidan dinyatakan dengan $\mathrm{IC}_{50}$ yaitu konsentrasi zat dimana mampu menginhibisi atau meredam absorbansi DPPH sebanyak 50\% (Julizan, et al., 2019). Nilai $\mathrm{IC}_{50}$ didapatkan berdasarkan analisis regresi linier konsentrasi larutan ekstrak etanol $S$. doederleinii dengan persentase inhibisi absorbansi DPPH. Berdasarkan data Tabel 3 dapat dibuat grafik antara konsentrasi larutan ekstrak dengan persentase peredaman absorbansi atau inhibisi DPPH, yang disajikan pada Gambar 10.

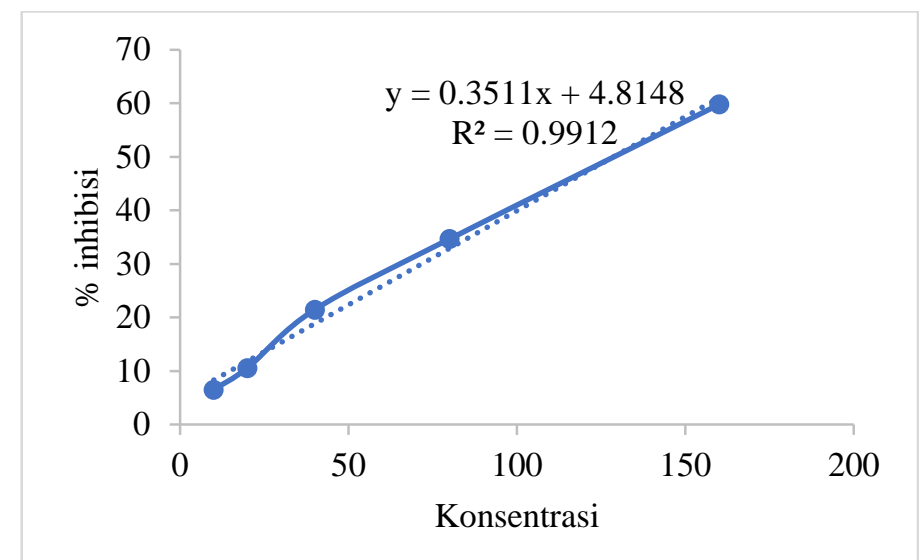

Gambar 10. Hubungan konsentrasi larutan ekstrak dan persentase inhibisi DPPH

Berdasarkan Gambar 10 didapatkan persamaan regresi $\mathrm{y}=0,3511 \mathrm{x}+4,8148$. Kemudian memasukkan nilai y dengan $50 \%$ diperoleh nilai $\mathrm{x}$ atau $\mathrm{IC}_{50}$ sebesar $128,696 \mathrm{ppm}$. Karena harga $\mathrm{IC}_{50}$ terdapat direntang 100-250 ppm maka aktivitas antioksidan dari ekstrak etanol tumbuhan paku $S$. doederleinii termasuk kategori sedang (Rahman, et al., 2014).

Aktivitas antioksidan ekstrak etanol tumbuhan paku S. doederleinii disebabkan oleh kandungan senyawa metabolit sekunder jenis fenolik khususnya flavonoid (Heim, et al., 2002). Senyawa fenolik yang berupa flavonoid berpotensi sebagai antioksidan. Aktivitas antioksidan flavonoid disebabkan karena adanya gugus hidroksil fenolik yang mampu menetralkan radikal bebas melalui donor atom hidrogen. Al-Farsi, et al. (2007) menyatakan bahwa kandungan flavonoid total dan aktivitas antioksidan saling berhubungan. Semakin besar kandungan flavonoid total suatu zat maka semakin besar pula kemampuan antioksidannya.
Peran flavonoid dalam aktivitas antioksidan yaitu dengan mendonorkan atom hidrogen atau dengan kemampuannya mengikat logam, dalam bentuk glukosida (terdapat rantai glukosa) sedangkan dalam bentuk bebas disebut aglikon. Jika semakin sedikit ikatan gula maka sifat antioksidannya semakin tinggi (Arifin \& Ibrahim, 2018).

Kemampuan senyawa flavonoid dalam aktivitas antioksidan juga tergantung pada penyusunan gugus fungsi dalam struktur intinya. Jumlah gugus hidroksil secara signifikan akan berpengaruh terhadap aktivitas antioksidan. Gugus hidroksil tambahan di cincin B (gugus pyrogallol) dapat meningkatkan kapasitas antioksidan. Di sisi lain, kehadiran hanya satu hidroksil di cincin B dapat mengurangi aktivitas antioksidan. Sedangkan substitusi pada cincin A dan $\mathrm{C}$ memiliki dampak yang kecil pada aktivitas antioksidan (Pieta, 2000). 


\section{Kesimpulan}

Berdasarkan hasil penelitian yang telah dilakukan dapat disimpulkan bahwa ekstrak etanol tumbuhan paku $S$. doederleinii mempunyai kandungan senyawa metabolit sekunder golongan fenol, flavonoid, alkaloid, steroid, saponin, tanin. Kandungan flavonoid total sebesar $17,615 \mathrm{mg}$ QE/g ekstrak serta aktivitas antioksidan berkategori sedang dengan nilai $\mathrm{IC}_{50}$ sebesar $128,696 \mathrm{ppm}$.

\section{Daftar Pustaka}

Al-Farsi, M., Alasalvar, C., Al-Abid, AlShoaily, M., Al-Amry, M., AlRawahy, F., 2007. Compositional and Functional Characteristics of Dates, Syrups, and Their byProducts. Food Chemistry, Volume 104, 943-947.

Arifin, B. \& Ibrahim, S., 2018. Struktur, Bioaktivitas dan Antioksidan Flavonoid. Zarah, 6(1), 21-29.

Chikmawati, T., Sopyati, P. D. \& M., 2013. Pertumbuhan dan analisis kualitatif tanin, saponin dan flavonoid dari Selaginella plana, S. willdenovii and S. mayeri pada tiga naungan berbeda. Bioslogos, 3(1), 1-9.

Dalimartha, S., 1999. Atlas Tumbuhan Obat Indonesia, Jilid I. Jakarta: Trubus Agriwidya.

Depkes, RI., 1989. Materia Medika Indonesia. Jilid V ed. Jakarta: Departemen Kesehatan Republik Indonesia.

Farah, J., Y. \& Marpaung, M. P., 2019. Ekstrak Etil Asetat Daun Jambu Biji Merah (Psidium guajava L.) sebagai Antioksidan secara In vitro. JFL : Jurnal Farmasi Lampung, 8(2), 78-86.

Gandjar, G. \& Rohman, A., 2007. Kimia Farmasi Analisis. Yogyakarta: Pustaka Pelajar.

George, V., Kumar, D., Suresh, P. \& Kumar, R., 2015. Antioxidant, DNA Protective Effecacy and HPLC Analysis of Annona muricata (soursop) extracts. Journal of Food Science and Technology, 52(4), 2238-2335.

Haeria, H. \& Andi, T., 2016. Penentuan Kadar Flavonoid Total dan Aktivitas Antioksidan Ekstrak Etanol Daun Bidara (Ziziphus spina-christi L.). Journal of Pharmaceutical and Medicinal Science, 1(2), 57-61.

Heim, K., Tagliaferro, A. \& Bobilya, D., 2002. Flavonoid Antioxidants : Chemistry, Metabolisme and Stucture-Activity. Journal of Nutritional Biochemistry, Volume 13, 572-584.

Hutapea, J., 1999. Investaris Tanaman Obat Indonesia, Jilid V. Jakarta: Departemen Kesehatan RI dan Badan Penelitian dan Pengembangan Kesehatan.

Jati, N., Prasetya, A. T. \& Mursiti, S., 2019. Isolasi, Identifikasi, dan Uji Aktivitas Antibakteri Senyawa Alkaloid Pada Daun Pepaya. Jurnal MIPA, 42(1), 1-6.

Julizan, N., Maemunah, S., Dwiyanti, D. \& Anshori, J., 2019. Validasi Penentuan Aktifitas Antioksidan Dengan Metode DPPH. KandagaMedia Publikasi Ilmiah Jabatan Fungsional Tenaga Kependidikan, 1(1), 41-45.

Lindawati, N. \& Ma'ruf, S., 2020. Penetapan Kadar Total Flavonoid Ekstrak Etanol Kacang Merah (Phaseolus vulgaris L.) secara Spektrofotometri Visibel. Jurnal Ilmiah Manuntung, 6(1), 83-91.

Lin, R., Skaltsounis, A.L., Seguin, E., Tillequin, F., Koch, M., 1994. Phenolic Constituents of Selaginella doederleinii. Planta Medica, 60(2), 168-170.

Marliana, E., 2005. Aktivitas Antioksidan Ekstrak Etanol Daun Andong (Cordyline fruticosa [L] A. Cheval). Jurnal Mulawarman Scientifie. 11(1), 71-82. 
McMurry, J. \& Fay, R., 2004. McMurry Fay Chemistry. 4th edition ed. CA: Pearson Education International.

Octaviani, M., Fadhli, H. \& Yuneistya, E., 2019. Uji Aktivitas Antimikroba Ekstrak Etanol dari Kulit Bawang Merah (Allium cepa L.) dengan Metode Difusi Cakram. Pharmaceutical Sciences and Research, 6(1), 62-68.

Paknahad, Z. Parisa, S., Teimouri, Z., Hasanzadeh, A., Hashemi, M.l., 2020. Dietary total antioxidant capacity and severity of stenosis in patients with coronary artery disease. International Journal for Vitamin and Nutrition Research, 91(3-4), 235-241.

Pasaribu, S., 2009. Uji Bioaktivitas Metabolit Sekunder Dari Daun Tumbuhan Bandotan (Ageratum conyzoides L.). Jurnal Kimia Mulawarman. 6(2), 23-29.

Pieta, P.-G., 2000. Review Flavonoids as Antioxidants. Journal of Natural Products, 63(7), 1035-1042.

Rahman, N., Bahriul, P. \& Diah, A., 2014. Uji Aktivitas Antioksidan Ekstrak Daun Salam (Syzygium Polyanthum) dengan Menggunakan 1,1-Difenil-2Pikrilhidrazil. Jurnal Akademika Kimia, 3(3), 143-149.

Rindita, Anggia, VIvi, Rahmaesa, Eka, Devi, Retna K., Alawiyah, Lidia Fatmah., 2020. Exploration, phenolic content determination, and antioxidant activity of dominant pteridophytes in Gunung Malang Village, Mount Halimun SalakNational Park, Indonesia. Biodiversitas, 21(8), 3676-3682.

Setiabudi, D. \& Tukiran, 2017. Uji Skrining Fitokimia Ekstrak Metanol Kulit Batang Tumbuhan Klampok Watu (Syzygium litorale). Unesa Journal of Chemistry, 6(3), 155-160.

Shahwar, D., Rehman, S., Ahmad, N. \& Raza, M., 2010. Antioxidant
Activities of The Family Euphorbiaceae, Lauraceae, Malvaceae, and Balsaminaceae. African Journal of Biotechnology, Volume 9, 1086-1096.

Simaremare, E., 2014. Skrining Fitokimia Ekstrak Etanol Daun Gatal (Laportea decumana (Roxb.) Wedd). Pharmacy, 11(1), 98-107.

Sriwahyuni, I., 2010. Uji Fitokimia Ekstrak Tanaman Anting-Anting (Acalypha Indica Linn) dengan Variasi Pelarut dan Uji Toksisitas menggunakan brine shrimp (artemia salina leach), Malang: Fakultas Sains dan Teknologi Universitas Islam Negeri Maulana Malik Ibrahim.

Sulasmi, S., M. \& Z., 2019. Tanin Identification of 4 Species Pterydophyta from Baluran National Park. Journal of Physics: Conf. Series, 1(2).

Suyani, H., 1991. Kimia dan Sumber Daya Alam, Padang: Pusat Penelitian Universitas Andalas.

Taba, P., Paramitha, N. \& Kasim, S., 2019. Sintesis nanopartikel Perak menggunakan Ekstrak Daun Salam (Syzygium polyanthum) sebagai Bioreduktor dan Uji Aktivitasnya sebagai Antioksidan. Indo. J. Chem. Res, 7(1), 51-60.

Trinovita, Y., Mundriyastutik, Y., Fanani, Z. \& Fitriyani, A. N., 2019. Evaluasi Kadar Flavonoid Total Pada Ekstrak Etanol Daun Sangketan (Achyranthes Aspera) Dengan Spektrofotometri. Indonesia Jurnal Farmasi, 4(1), 12-18.

Triwahyuono, D. \& Hidajati, N., 2020. Uji Fitokimia Ekstrak Etanol Kulit Batang Mahoni (Swietenia mahagoni Jacq). Unesa Journal of Chemistry, 9(1), 54-57.

Widyasari, E. Sriyani, M.E., Daruwati, I., Halimah, I., Nuraeni, W., 2019. Karakteristik Fisika-Kimia Senyawa bertanda 99mTc- 
Kuersetin. Jurnal Sains dan

Teknologi Nuklir Indonesia, 20(1),

9-18.

Winarti, W., Djamil, R. \& Yuniasari, I., 2007. Identifikasi Senyawa Flavonoid dalam Fraksi n-Butanol Taraxacum officinale, Asteraceaea. Ikatan Apoteker Indonesia, 5(2), 59-66. 